\title{
POSISI INDONESIA DALAM KONFLIK LAUT TIONGKOK SELATAN
}

\author{
Yuniarti Dwi Pratiwi ${ }^{1}$
}

\begin{abstract}
Abstrak: Kawasan Laut Tiongkok Selatan (LTS) ditinjau dari aspek ekonomi memiliki nilai strategis terhadap perkembangan ekonomi negara-negara di kawasan Asia Pasifik. Kawasan ini, telah lama menjad iajang perebutan beberapa negara sekitar kawasan dengan berbagai alasan, mulai dari politik, ekonomi, pertahanan, dan lain-lain.Begitu pula dengan Pemerintah Tiongkok yang turut serta dalam mengklaim Laut Tiongkok Selatan (LTS) tersebut, yaitu melalui kebijakan $U$-Shaped Line atau sering dikenal sebagai sembilan garisputus-putus (nine dash lines).Tidak dapat dipungkiri bahwa Laut Tiongkok Selatan memiliki arti yang sangat strategis bagi Bangsa Indonesia, meskipun Indonesia bukan Negara yang turut sertamenuntutklaimataskepemilikanwilayah territorial di Laut Tiongkok Selatan. Namuncepat atau lambat dikhawatirkan akan berpengaruh pada kedaulatan Bangsa ini. Ini dapat dilihat setelah adanya konflik penangkapan Anak Buah Kapal (ABK) milik Pemerintahan Tiongkok yang memasuki Perairan Natuna secara illegal, yang mana merupakan daerah Zona Ekonomi Eksklusif (ZEE) Negara Kesatuan Republik Indonesia.Atas dasar inilah sangat penting untuk mengkaji kedudukan Laut Tiongkok Selatan menurut pandangan Hukum Internasional serta posisi LTS bagi Negara Indonesia.
\end{abstract}

Kata kunci:LautTiongkok Selatan, Nine Dash Line, Natuna, Zona Ekonomi Ekslusif, Natuna

\section{PENDAHULUAN}

Perairan merupakan salah satu bagian dari negara yang mempunyai fungsi strategis dalam kegiatan ekonomi. Ini disebabkan kegiatan ekonomi lintas batas negara-negara di dunia mengggunakan laut sebagai jalur distribusi utama.Tentunya, setiap negara yang memiliki pantai juga memiliki hak untuk memiliki wilayah perairan. Namun, rancunya batas perairan apalagi didukung dengan aspek sejarah wilayah perairan tersebut, maka tidak menutup kemungkinan akan timbul konflik antara negara-negara di sekitar kawasan tersebut.

Laut Tiongkok Selatan merupakan sebuah wilayah perairan yang menjadi salah satu sumber ketegangan yang terjadi di sekitarwilayah Asia Timur dan Asia Tenggara. Ketegangan ini dipicu oleh Pemerintah Tiongkok yang mengeluarkan nine dash lines dan membangun pangkalan militer secara sepihak di wilayah perairan Laut Tiongkok Selatan. Konflik di wilayah perairan ini pada

\footnotetext{
${ }^{1}$ Penulis adalah pemerhati pertahanan di Lembaga Kajian Pertahanan untuk Kedaulatan NKRI "KERIS". Penulis dapat dihubungi melalui email yuniartiibbas@gmail.com
}

akhirnya melibatkan beberapa negara berdaulat di wilayah tersebut. Negara yang terseret ke dalam konflik Laut Tiongkok Selatan adalah Brunei Darussalam, Republik Rakyat Tiongkok, Taiwan, Malaysia, Filipina, dan Vietnam. ${ }^{2}$ Selain letak Laut Tiongkok Selatan berada pada posisi strategis karena berada dalam jalur palayaran perdagangan (SLOT) dan jalur komunikasi Internasional (SLOC) yang menguhubungkan Samudera Hindia dan Samudera Pasifik, juga karena muncul spekulasi di Dunia Internasional bahwa pulau-pulau di sekitar perairan tersebut memiliki berbagai macam sumber energi yang melimpah,. ${ }^{3}$

$\begin{array}{rr}\text { Sebagaimana } & \text { disebutkan } \\ \text { sebelumnya, motivasi } & \text { terbesar }\end{array}$

\footnotetext{
${ }^{2}$ Ali, Maksum, Regionalisme dan Kompleksitas Laut China Selatan, Jurnal Sosial Politik Universitas Muhammadiyah Yogyakarta, Volume 2 Nomor 2 (Januari-Juni 2017) Hal 1-23

${ }^{3} \mathrm{Wu}$, Sichun, Memahami Perspektif TIongkok Dalam Upaya Penyelesaian Sengketa Laut Cina Selatan, Judul Buku (Solving Diputes for Regional Cooperation and Development in the South China Sea, A Chinese Perspective), Chandos Publishing, di terjemahkan oleh Peneliti Pusat Penelitian Politik, Lembaga Ilmu Pengetahuan Indonesia (25 Juni 2014) hal 168
} 
Pemerintah Tiongkok dalam menciptakan ketegangan di Laut Tiongkok Selatan (LTS), yang mana setiap tindakannya sangat sarat dengan konflik dengan mengklaim LTS sebagai wilayah kedaulatannya, adalah faktor ekonomi dan militer.Upaya Beijing dalam mengukuhkan kedaulatannya di Laut Tiongkok Selatan tidak lain merupakan cita-cita Pemerintah Tiongkok untuk menghidupkan kembali Jalur Sutera yang hingga abad ke-13 aktidigunakansebagaijalurperdagangan.D asar landasan Pemerintah Tiongkok dalam mengklaim Laut Tiongkok Selatan adalah'sembilan garis putus-putus' (ninedashed lines) yang tercantum pada peta yang diproduksi oleh Departemen Geografi Kementerian Dalam Negeri Republik Tiongkok pada tahun $1947 .^{4}$

Walaupun Indonesia bukan negara yang ikut menuntut klaim atas kepemilikan wilayah di Laut Tiongkok Selatan,tidak dapat dipungkiri bahwa LTS memiliki arti strategis bagi Bangsa Indonesia sehingga sangat perlu menjadi perhatian Pemerintah Indonesia.Mengingat kondisi sempat memanas karena insiden illegal fishing yang dilakukan oleh Kapal-kapal Tiongkok di Perairan Natuna yang sudah sangat jelas merupakan yurisdiksi Indonesia.Salah satu kasus yang sempat heboh adalah bentrok antara kapal perang Indonesia dan kapal berbendera Tiongkok ketikaKRI Imam Bonjol menangkap kapal ikan "Han Tan Cou 19038" yang tertangkap basah beroperasi secara illegaldi wilayah Laut Natuna pada pertengahan Juni Tahun 2016. ${ }^{5}$

Atas dasar inilah maka penting untuk mengkaji status kedudukan Laut

\footnotetext{
${ }^{4}$ Kepentingan Politik China Dalam Konflik Region Sengketa Perebutan Territorial Kawasan Laut China Selatan, (https://www.academia.edu/9326843/KEPENTING AN_POLITIK CHINA DALAM_KONFLIK RE GION_SENGKETA_PEREBUTAN_TERRITORI AL_KAWASAN_LAUUT_CHINA_SELATAN) diakses pada 8 Mei 2017

${ }^{5}$ Ini Kronologi Penangkapan Kapal Ikan di Natuna Versi Koarmabar (http://nasional.kompas.com/read/2016/06/21/1215 4071/ini.kronologi.penangkapan.kapal.ikan.china.d i.natuna.versi.koarmabar) diakses pada 8 Mei 2017
}

Tiongkok Selatan berdasarkan Hukum Internasional, serta posisi LTS bagi negara ini. Hal ini dikarenakan kompleksitas konflik pada perairan Laut Tiongkok Selatan, yang tidak menutup kemungkinan akan mengarah pada eskalasi konflik yang lebih besar, yang kemungkinan besar juga akan berdampak pada kedaulatan Negara Indonesia.

\section{SEJARAH KONFLIK LAUT TIONGKOK SELATAN}

Laut Tiongkok Selatan merupakan bagian dari Samudera Pasifik yang meliputi sebagian wilayah dari Singapura dan Selat Malaka hingga ke Selat Taiwan dengan luas sekitar 3.5 juta $\mathrm{km}^{2}$. LTSmerupakan wilayah perairan terluas kedua setelah kelima samudera di dunia dan di laut ini adalebih dari 200 pulau dan karang yang telah terindetifikasi, kebanyakan berada di Kepulauan Spartly. ${ }^{6}$ Namun, ketegangan yang barubaru ini terjadi di kawasan Laut Tiongkok Selatan menimbulkan kekhawatiran baru dan ditakutkan akan semakin mengancam keamanan dunia.Titik sengketa LTS yang diperebutkan negara kawasan dengan Republik Rakyat Tiongkok adalah sengketa kepemilikan Kepulauan Spartly dan Kepulauan Paracel.

Dalam sejarahnya, klaim kedaulatan Tiongkok terhadapgugusan kepulauan di LTSsudah berlangsung sangat lama.Klaim atas LTS ini berdasarkan atas hak historis yaitu faktor penemuan, penamaan, dan sejarah penyelenggaraan kekuasaan pemerintah yang telah berlangsung selama lebih dari 2.000 tahun.

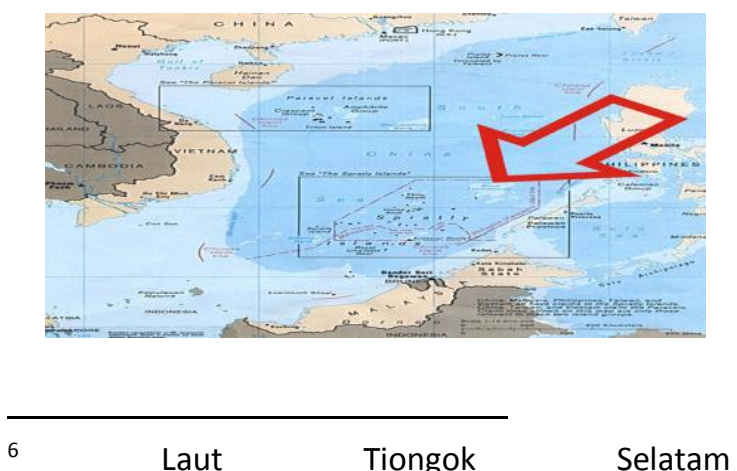
(https://id.wikipedia.org/wiki/Laut_Tiongkok_Selat an) 
(sumber : Berita Online Indonesia http://militaryanalysisonline.blogspot.co.id/201 3/09/sengketa-kepulauan-spratly-potensi.html)

Menurut Dr. Wu, Kepulauan Spratly (dalam bahasa Tionghoa: Nansha Qundao) merupakan pokok inti persoalan di LTS. Setidaknya ada enam negara yang mengklaim wilayah iniyaitu Tiongkok, Taiwan, Vietnam, Filipina, Malaysia dan Brunei Darussalam, yang mana mempunyai klaim dan pemberian nama terhadap pulau-pulau di Kepulauan Spartly. Sementara Brunei Darussalam hanya mengklaim wilayah laut di Kepulauan Spratly sebagai bagian dari Zona Ekonomi Eksklusif (ZEE) negaranya. ${ }^{7}$

Kepulauan Spratly sebenarnya bukan merupakan kepulauan yang layak huni, akan tetapi kepulauan ini memiliki banyak potensi sumber daya alam dan letak geografis yang sangat strategis. Kekayaan alam yang tersimpan di kepulauan ini membuat beberapa negara bersikeras untuk mengakui dan mengklaim wilayah tersebut. ${ }^{8}$ Selain itu, secara geografisLTS memiliki potensi dan peran yang sangat besar sebagai jalur pelayaran internasional dan jalur distribusi minyak.Kawasan ini merupakan kawasan lintas laut yang sangat strategis sehingga mampu melambungkan perekonomian negara.Sebagai leher dari Samudra Pasifik dan Samudra Hindia, LTS menghubungkan perdagangan negaranegara maju di Asia, Amerika, dan Eropa.Hal ini dapat dibuktikan oleh Singapura dan Hong Kong, dua kota pelabuhan utama di dunia yang terletak di bagian utara dan selatan LTS. Fitur-fitur daratannya membentang sekitar 1.000

\footnotetext{
${ }^{7} \mathrm{Wu}$, Sichun Memahami Perspektif Tlongkok Dalam Upaya Penyelesaian Sengketa Laut Cina Selatan, Judul Buku (Solving Diputes for Regional Cooperation and Development in the South China Sea, A Chinese Perspective), Chandos Publishing, di terjemahkan oleh Peneliti Pusat Penelitian Politik, Lembaga Ilmu Pengetahuan Indonesia (25 Juni 2014)

${ }^{8} \mathrm{Ibid}$
}

kilometer dari tenggara ke barat daya di LTS. $^{9}$

\section{LAUT TIONGKOK SELATAN DI MATA DUNIA INTERNASIONAL}

1. Letak Strategis

Secara Geografis,LTS dikelilingi sepuluh Negara pantai (RRT, Taiwan, Vietnam, Kamboja, Thailand, Malaysia, Singapura, Indonesia, Brunei Darusalam, dan Filiphina). Luas perairan Laut Tiongkok Selatan mencakup Teluk Siam yang dibatasi Vietnam, Kamboja, Thailand, dan Malasiya serta Teluk Tonkin yang dibatasi Vietnam dan RRT. Kawasan LTS merupakan kawasan bernilai ekonomis, politis dan strategis sebagai jalur perdagangan (SLOT) dan jalur komunikasi Internasional (SLOC) yang menghubungkan Samudera Hindia dan Samudera Pasifik. Hal ini telah merubah jalur LTS menjadi jalur laut tersebuk di dunia, karena lebih dari setengah perdagangan dunia berlayar melewati LTS setiap tahunnya; ${ }^{10}$

2. Potensi ekonomi dan geopolitik

Kandungan kekayaan alam yang
ada di dalamnya telah
menyebabkan terjadinya konflik
wilayah antara Tiongkok dan
sebagian negara-negara ASEAN
yang berada di wilayah Laut
Tiongkok Selatan.Menurut U.S.
Energy Information Administration
(EIA) potensi sumber daya alam di
LTS sangat besar. Diperkirakan
LTS mempunyai kandungan

\footnotetext{
${ }^{9}$ Sengketa Kepulauan Spratly, Potensi Konflik di Asia Tenggara (http://militaryanalysisonline.blogspot.co.id/2013/0 9/sengketa-kepulauan-spratly-potensi.html) diakses pada tanggal 3 Mei 2017

${ }^{10}$ Karmin, Suharna, Konflik dan Solusi Laut Cina Selatan dan Dampaknya bagi Ketahanan Nasional, 2012, MA Majalah Tamnas Edisi 94
} 
minyak sekitar 11 milyar barrel dan gas alam yang mencapai 190 trilyun kaki kubik (Tfc) serta cadangan hidrokarbon yang sangat penting sebagai pasokan energy, sedangkan konsultan energi Wood Mackenzie, memperkirakan cadangan minyak dan gas memperkirakan Laut Tiongkok Selatan mengandung 2,5 miliar barel ${ }^{11}$

\section{NEGARA-NEGARA \\ YANG \\ BERSENGKETA DI LAUT TIONGKOK SELATAN}

\begin{abstract}
Sebagai mana kita ketahui bahwa potensi sumber daya alam yang sedemikian besar memicu persaingan negara-negara di LTS untuk menguasai wilayah tersebut.Sebagian besar negara di sekitar LTS mempunyai klaim dalam skala yang berbeda-beda. Secara spesifik, beberapa negara secara resmi mengklaim LTS sebagai berikut :
\end{abstract}

1. Tiongkok mengklaim bahwa LTS merupakan wilayah kedaulatannya, Tiongkok berpedoman pada latar belakang sejarah Tiongkok kuno tentang peta wilayah kedaulatan Tiongkok. Menurut Tiongkok, pulau dan wilayah laut LTS ditemukan oleh pendahulu Tiongkok yakni Dinasti Han sejak 2 abad sebelum Masehi. Kemudian pada abad 12 sebelum Masehi oleh Dinasti Yuan pulau-pulau dan wilayah laut di LTS di masukkan kedalam peta teritori Tiongkok. Kemudian diperkuat dengan Dinasti Ming dan Dinasti Qing pada abad ke 13 sebelum Masehi. Pada tahun 1947 Tiongkok memproduksi peta Laut Tiongkok Selatan dengan 9 garis putus-putus

\footnotetext{
${ }^{11}$ U.S. Energy Information Administration (https://www.eia.gov/beta/international/regionstopics.cfm?RegionTopicID=SCS) diakses pada 29 April 2017
}

dan membentuk huruf $U$, serta menyatakan semua wilayah yang ada di dalam di garais merah putus-putus tersebut adalah wilayah teritorial Tiongkok. Maka, sejak tahun 1976 Tiongkok telah menduduki beberapa pulau di Kepulauan Paracel dan pada tahun 1992 hukum Tiongkok menegaskan kembali klaim tersebut;

2. Posisi Taiwan dalam konflik LTS bisa dikatakan menarik. Karena kawasan klaim Taiwan di LTS tidak lain adalah wilayah klaim Tiongkok itu. Persamaan sejarah politik membuat Taiwan merasa mempunyai hak yang sama atas wilayah LTS,sedangkan Tiongkok masih menganggap Taiwan sebagai salah satu provinsinya. Dalil klaim Taiwan adalah berdasarkan sejarah negara tersebut terutama pasca pemisahan diri dari Tiongkok yang dipimpin oleh Chiang Kaishek. Pada tahun 1947,Pemerintah Kuomintang membuat peta resmi yang memasukkan wilayah-wilayah klaim termasuk seluruh kawasan LTS termasuk Kepulauan Spratly, Kepulauan Paracel, Pulau Pratas, dan Scarborough Reef ke dalam teritorial Taiwan. Dalam konteks klaim Taiwan di LTS, Taiwan terfokus pada sebuah pulau yang dikenal dengan Pulau Itu Aba yang merupakan pulau terbesar di Kepulauan Spratly (Boston Global Forum, 2015; Gewirtz, 2016; Lunn, 2016). Konsekensinya, garis ZEE Taiwan semakin luas bahkan menjangkau pulaupulau sekitar LCS. ${ }^{12}$

\footnotetext{
${ }^{12}$ Ali, Maksum, Regionalisme dan Kompleksitas Laut China Selatan, Ali Maksum, Jurnal Sosial Politik Universitas Muhammadiyah Yogyakarta, Volume 2 Nomor 2 (Januari-Juni 2017) Hal 7-14
} 
3. Filipina menjadi salah satu negara yang penting dalam konflik LTS. Selain itu, Filipina termasuk menjadi negara yang paling awal melakukan aktivitas strategis di LTS. Pada tahun 1970-an, Filipina telah melakukan eksplorasi di kawasan Reed Bank yang merupakan bagian Kepulauan Spratly. Usaha keras Filipina membuahkan hasil dengan ditemukannya sumber gas alam pada tahun 1976 di kawasan tersebut. Tindakan Filipina langsung diprotes Tiongkok dan mendesak Manila untuk segera menghentikan aktivitas tersebut. Namun, keadaan justru semakin memanas karena Presiden Ferdinand Marcos mengeluarkan Dekrit Presiden pada tanggal 11 Juni 1978 yang memasukkan Kepulauan Spratly yang mereka kenal sebagai Kelompok Kepulauan Kalayaan ke dalam wilayah teritorial Filipina: ${ }^{13}$

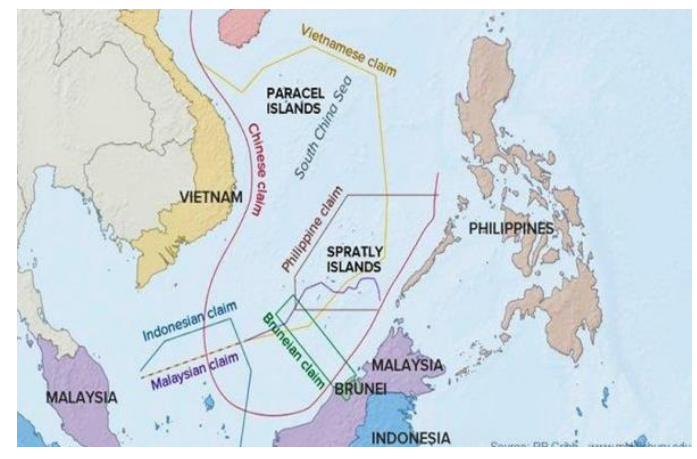

(sumber

http//:www.bbc.com/indonesia/laporan khusus /2011/07/110719 spratlyconflict)

4. Klaim Malaysia atas sebagian wilayah Spartly adalah berdasarkan bukti sejarah warisan penjajah Inggris.Klaim Malaysia adalah (1) sejauh 12 mil laut, termasuk (2) ZEE yang berdampak pada (3) perluasan luas landasan kontinen hingga ke LTS. Kemudian pada tanggal 21 Desember 1979 diterbitkan Peta Baru, yang kemudian mengkukuhkan secara resmi ZEE. Berkaitan dengan itu Malaysia telah membuat batas yang diklaimnya dengan koordinat yang jelas;

5. Negara Brunei Darussalam tidak mengklaim pulau-pulau, tetapi mengklaim bagian dari Laut Tiongkok Selatan yang terdekat sebagai bagian dari Landas Kontinen dan ZEE. Atas dasar inilah, pada Tahun 1984 Brunei mengumumkan ZEE di Kepulauan Spartly meliputi Lousa Reef;

6. Klaim Vietnam di LTS juga didasari oleh bukti sejarah penjajah sebelumnya yaitu Prancis. Ketika menguasasi Vietnam, pemerintah kolonial Prancis melakukan beberapa ekspedisi ke LTS termasuk Kepulauan Spratly dan Kepulauan Paracel. Pada awalnya ketika Vietnam terbelah menjadi Republik Demokratik Vietnam atau Vietnam Utara (di bawah Ho Chi Minh) dan The State of Vietnam atau Vietnam Selatan (di bawah Bao Dai) sikap Prancis berbeda. Ketika itu, Prancis yang mendukung Vietnam Selatan memasukkan Kepulauan Paracel dalam wilayah teritorialnya. Namun, Prancis menolak klaim Vietnam Selatan atas Kepulauan Spratly karena sudah diklaim Prancis. Menariknya, pasca Perang Dingin, terjadi persaingan sengit antara Vietnam dan China untuk mendekati negaranegara ASEAN agar mendapat dukungan terkait klaim di LCS (Tonnesson, 2001). ${ }^{14}$ 
7. Indonesia tidak termasuk negara yang turut serta dalam mengklaim LTS. Namun klaim Tiongkok melalui nine dash line yang membentuk huruf $U$ turut mencaplok sebagian ZEE Indonesia yang berada di perairan Kepulauan Natuna. ${ }^{15}$

Adanya berbagai klaim tersebut membuatsengketa yang terjadi di Laut Tiongkok Selatan dapat berdampak pada eskalasi konflik dalam skala yang lebih besar.

\section{Nine Dash Linedi Mata Hukum Internasional}

Sengketa perebutan teritorial LTSdinilai semakin meluas dan sengit. Jika dilihat dalam kacamatan Hukum Internasional, akan sangat kental terlihat benturan kepentingan setiap negaranegara yang bersengketa. Pijakan hukum resmi atas klaim wilayah terhadap LTS oleh 4 anggota ASEAN (Vietnam, Malaysia, Filipina, dan Brunei) mengacu pada Konvensi PBB tentang Hukum Laut UNCLOS (United Nation Convention Law Of The Sea) yang ditandatangani oleh 119 negara pada tanggal 10 Desember 1982. Perlu diketahui UNCLOS 1982 merupakan Konvensi PBB tentang Hukum Laut yang memuat upaya paling komprehensif PBB untuk menciptakan sebuah peraturan terpadu untuk tata kelola hak-hak negara di dunia terhadap lautan. Perjanjian itu membahas sejumlah topik antara lain hak navigasi, hak ekonomi, pencemaran laut, konservasi kehidupan laut, eksplorasi ilmiah, dan perompakan.Dengan diberlakukannya UNCLOS 1982, diharapkan sengketa perbatasan antar negara yang mempunyai wilayah laut bisa diselesaikan. ${ }^{16}$

Konvensi PBB tentang Hukum Laut (UNCLOS) yang diratifikasi oleh negara anggota PBB tahun 1982 memberikan pengaruh terhadap sengketa wilayah LTS.Bagian terpenting dari UNCLOS

15 Karmin, Surana, Konflik dan Solusi Laut Cina Selatan dan Dampaknya bagi Ketahanan Nasional, Majalah Tamnas Edisi 94

${ }^{16}$ Ibid untuk sengketa iniadalah memberikan hak kepada setiap negara untuk memperoleh ZEEsejauh 200 mil. Di dalam wilayah ZEE ini, wilayah, daerah, atau negara yang memiliki pantai berhak untuk menggali kekayaan alam yang dimiliki di zona tersebut, serta dapat melakukan kegiatankegiatan ekonomi tertentu lainnya, seperti kegiatan eksplorasi dan eksploitasi sumber daya alam di permukaan laut, di dasar laut, dan di bawah laut. Negara tersebut juga memiliki hak untuk melakukan penelitian sumber daya hayati maupun sumber daya alam laut lainnya. Wilayah diluar ZEE akan dianggap sebagai International Waters (Perairan Internasional) yang tidak boleh dieksploitasi oleh Negara manapun, termasuk negara yang bersengketa di wilayah Laut Tiongkok Selatan (LTS). ${ }^{17}$

Atas dasar inilah maka empat Negara ASEAN (Vietnam, Flliphina, Malasiya, dan Brunei Darusalam) mendesak agar Tiongkok menaati resolusi UNCLOS yang disebutkan diatas.Bagi Tiongkok, ratifikasi ini merugikan mereka karena wilayah teritorial yang diklaim Tiongkok berupa titik merah yang membentuk huruf $U$ atau yang dikenal sebagai Nine Dash Line (Sembilan garis putus-putus). Hal ini tentunya bertentangan dengan prinsip Konvensi PBB tentang Hukum Laut (UNCLOS 1982). ${ }^{18}$ Sejak tahun 2013, Filipina telah menggugat klaim Tiongkokatas daerah yang mereka sebut sebagai West Philipine Sea ke Permanent Court of Abitration (PCA).Dalam gugatan tersebut Filipina mengatakan klaim Tiongkok atas daerahdaerah tersebut tidak berdasar karena bertentangan dengan Konvensi PBB (UNCLOS 1982). ${ }^{19}$

\footnotetext{
17 Tjondro Titamulia, Zona-Zona Laut UNCLOS, Surabaya, Brilian Internasional, 2011 (hal 45-57)

${ }^{18}$ Karmin, Surana, Konflik dan Solusi Laut Cina Selatan dan Dampaknya bagi Ketahanan Nasional, Majalah Tamnas Edisi 94

${ }^{19}$ Apa Pengaruh Putusan Mahkamah Arbitrase Soal Laut Cina Selatan (www.bbc.com/indonesia/dunia/.../160711_dunia_f ilipina_cina_mahkamah_preview) diakses 29 April 2017
} 


\section{HASIL KEPUTUSAN PENGADILAN ARBITRASE TERHADAP KONFLIK LAUT TIONGKOK SELATAN}

Pada tanggal 12 Juli 2016, Pengadilan Arbitrase (PCA) di Den Haag, Belanda, memutuskan keberpihakannya terhadap Filipina atas sengketa terkait LTS.Putusan itu sesuai dengan keberatan yang diajukan oleh Filipina.Pengadilan Arbitrase menyatakan tidak ada bukti sejarah bahwa Tiongkok menguasai dan mengendalikan sumber daya secara eksklusif di LTS.Pengadilan menyimpulkan bahwa dalam kasus Filipina dan Tiongkok, tidak ada landasan hukum bagi Tiongkok untuk mengklaim hak eksplorasi kekayaan alam di sepanjang area yang mereka sebut ninedash lines. ${ }^{20}$

Hal ini dapat diperjelas karena dalam Hukum Laut Internasional, unsur daratan dapat dibagi ke dalam beberapa bagian :

a. Pulau. Agar bisa disebut pulau, sebuah daratan di tengah laut harus bias menunjang habitat manusia atau kehidupan ekonomi secara mandiri. Jika sebuah Negara memiliki pulau, Negara itu berhak atas Zona Ekonomi Ekslusif, atau dengan kata lain hak memanfaatkan sumber daya alam (termasuk menangkap ikan atau mengeksplorasi gas dan minyak), di sekitar pulau dalam radius 200 mil laut;

b. Karang.Unsur daratan ini didefinisikan sebagai bebatuan di atas permukaan laut ketika air pasang, terleps berapapun besarnya. Sebuah Negara yang memiliki karang berhak atas wilayah dalam radius 12 mil laut dari karang tersebut;

c. Terumbu.Unsur daratan ini hanya bisa terlihat saat air laut surut.Sebuah Negara yang

\footnotetext{
${ }^{20}$ Klaim Cina di Laut Cina Selatan 'tak punya landasan hukum (www.bbc.com/indonesia/dunia/2016/07/160712_d unia_putusan_lautcinaselatan) diakses 9 Mei 2017
}

menguasai terumbu tidak memiliki hak atas sumber daya alam atau wilayah perairan apapun disekitarnya. ${ }^{21}$

Dari ketiga unsur tersebut, Tiongkok jelas telah melanggar UNCLOS 1982.Selain itu, pulau-pulau buatan yang dilengkapi dengan pelabuhan dan pangkalan militer tidak sah menurut putusan Pengadilan Arbitrase.Keputusan yang dihasilkkan oleh Pengadilan Arbitrase terkait LTS bersifat mengikat, namun pengadilan tidak memiliki kekuatan untuk melakukan pemaksaan.

\section{DAMPAK HASIL PENGADILAN ARBITRASE ATAS KONFLIK LAUT TIONGKOK SELATAN}

Hasil sidang Pengadilan Arbitrase PBB di Den Haagmemutuskan Tiongkok tak memiliki dasar hukum untuk mengklaim seluruh wilayahLTS.Menanggapi keputusan itu, pemerintah Beijing merilis pernyataan resmi berupa penolakan Tiongkok atas keputusan tersebut.Sikap Tiongkokini membuat Dunia Internasional terhenyak. Hal ini dapat dilihat dari tensi politik maupun keamanan di kawasan sengketa yang akan semakin memanas. ${ }^{22}$ Begitu pula dengan hubungan Tiongkok dengan negara-negara pengklaim yang mayoritas merupakan negara ASEAN.Sikap penolakan ini juga ditunjukkan oleh Pemerintah Tiongkok dengan tetap melangsungkan pembangunan Pangkalan Militer di LTS, yang mana kawasan perairan tersebut masih disengketakan oleh sejumlah negara ASEAN.Pembangunan yang dilakukan Tiongkok secara sepihak ini semakin meningkatkan ketegangan di antara negara-negara yang menolak klaim Tiongkok terhadap LTS. Kondisi ini tentunyaakan berdampak pada Indonesia meskipun Indonesia tidak turut serta dalam aksi klaim wilayah perairan LTS. Akan tetapi apabila tidak ada solusi yang

\footnotetext{
${ }^{21}$ United Nation Convention of The Law Sea 1982

${ }^{22}$ Menakar Efek Susulan Sengketa di Laut Cina Selatan (www.citizendaily.net)diakses pada $6 \mathrm{Mei}$ 2017
} 
tepat baik jangka pendek maupun jangka panjang akan berdampak pada ketahanan nasional.

Sehubungan dengan ini, penting untuk mencari solusi yang tepat dalam penyelesaian konflik LTS mengingat pada pertengahan Tahun 2016 Tiongkok dengan percaya diri melakukan aksi klaim secara terhadap perairan Natuna. Klaim atas wilayah Natuna kedalam ZEE Tiongkok memberikan masalah baru kepada Indonesia.Dasar Pemerintah RRT adalahPerairan Natuna yang diklaim secara sepihak tersebut dianggap sebagai traditional fishing ground.Pemerintah Indonesia semakin geram dikarenakan beberapa kasus pecurian ikan yang dilakukan Tiongkok di perairan ini. ${ }^{23}$

Dalam kasus ini, sebenarnya Indonesia berada diposisi yang kuat daripada Tiongkok yang hanya berdasarkan pada aturan nine dash lines itu. Wilayah Perairan Natuna sudah jelas merupakan perairan Zona Ekonomi Ekslusif (ZEE) Indonesia, sebagaimana termaktub dalam Undang-Undang Nomor 5 Tahun 1983 tentang Zona Ekonomi Eksklusif yang merupakan implementasi dari Hukum Laut UNCLOS 1982.Dengan adanya tindakan Tiongkok yang melakukan illegal fishing dan klaim atas Perairan Natuna, maka sudah jelas bahwa Tiongkok harus mengikuti dan mematuhi segala aturan yang berlaku.

\section{DAMPAK SENGKETA LAUT TIONGKOK SELATAN TERHADAP INDONESIA}

Tidak bisa dipungkiri dampak konflik LTS dapat berdampak pada entitas Negara Kesatuan Republik Indonesia.Ini dapat dilihat dari sederet kasus kapal milik Tiongkok yang memasuki wilayah perairan Indonesia secara ilegal, dengan melakukan illegalfishing di Perairan Natuna, yang mana sudah jelas masuk dalam yurisdiksi Indonesia.Tindakan ini didasari atas klaim sepihak dari Tiongkok

\footnotetext{
23 Perbatasan Laut Natuna, Zee dan Klaim Traditional Fishing Ground Tiongkok (www.wilayahperbatasan.com/perbatasan-lautnatuna-zee-dan-klaim-traditional-fishing.html) diakses pada 6 Mei 2017
}

atas Natuna yang berdasarkan nine dash lines.Dalan kasus ini permasalahan bukan pada klaim kepulauannya saja tapi pada perairan sekitar Kepulauan Natuna juga.Dengan berdasarkan Nine Dash Lines yang tidak jelas batasnya, mengakibatkan timbulnya masalah atas hak berdaulat, terutama pada kedaulatan Indonesia atas wilayah Zona Ekonomi Ekslusif di wilayah Perairan Natuna.

Klaim sepihak ini sangat berakibat pada ketahanan dan keamanan negara kita. Ketahanan negara akan terusik oleh adanya konflik ini. Selain itu Negara ini akan dipandang oleh negara-negara lain sebagainegara yang lemah karena tidak mampu melindungi wilayahnya sendiri. Lebih ekstrim lagi, dampak dari kasus ini adalah kepercaayan masyarakat atas Pemerintah Indonesia akan berkurang. Serta tujuan negara yakni melindungi keutuhan NKRI menjadi tersendat dan tidak berjalan sesuai rencana.

Sedang untuk masalah keamanan negara, jelas hal ini akan berdampak besar. Dengan adanya klaim ini, penduduk Natuna bisa tertekan dan takut karena mereka menjadi subjek dari perebutan oleh Indonesia dan Tiongkok.Nelayan Indonesia, terutama nelayan Kepulauan Natuna dan ulaupulau sekitar merasa tidak aman dan hak mereka tidak terlindungi karenamaraknyalllegal Fishing oleh kapal milik Tiongkok. Lebih luas lagi apabila konflik LTS tidak segera diselesaikan, maka tidak menutup kemungkinan Indonesiaakan terseret ke dalam arus konflik LTS sebagaimana seperti yang dialami oleh negara-negara ASEAN lain dan Taiwan.

\section{KESIMPULAN}

Bagi Indonesia, meskipun sengketa yang terjadi di LTS berstatus Non Claimant States, apabila tidak ada solusi yang tepat baik jangka pendek maupun jangka panjang akan berdampak pada ketahanan nasional negeri ini. Karena apabila kita telaah, hakekat ketahanan kasional adalah keuletan dan 
ketangguhan bangsa yang mengandung kemampuan untuk menghadapi ancaman, hambatan dan gangguan guna menjamin kelangsungan hidup bangsa dan negara. Sebagaimana apa yang diamanatkan dalam tujuan Negara alinea ke 4 pada Pembukaaan Undang-Undang Dasar 1945 yaitu :

"Kemudian daripada itu untuk membentuk suatu Pemerintah Negara Indonesia yang melindungi segenap bangsa Indonesia dan seluruh tumpah darah Indonesia dan untuk memajukan kesejahteraan umum, mencerdaskan kehidupan bangsa, dan ikut melaksanakan ketertiban dunia yang berdasarkan kemerdekaan, perdamaian abadi dan keadilan sosial, maka disusunlah kemerdekaan kebangsaan Indonesia itu dalam suatu UndangUndang Dasar Negara Indonesia, yang terbentuk dalam suatu susunan Negara Republik Indonesia yangberkedaulatan rakyat dengan berdasar kepada Ketuhan Yang Maha Esa, Kemanusiaan yang adil dan berasab, Persatuan Indonesia, dan Kerakyatan yang dipimpin oleh hikmat kebijaksanaan dalam permusyawaratan/penwakilan, serta dengan mewujudkan suatu keadilan sosial bagi seluruh rakyat Indonesia."

Oleh karena itu, klaim sepihak atas Natuna oleh Tiongkoktidak dapat dibenarkan dan dapat mempengaruhi Ketahanan Nasional Bangsa ini dan tentunya akan berdampak pada kedaulatan NKRI. Padahal Ketahanan Nasional adalah sebuah landasan konseptual dalam penyelenggaraan sebuah negara.Hal ini dikarenakan ketahanan nasional merupakan keuletan dan ketangguhan bangsa yang mengandung kemampuan untuk menghadapi tantangan, ancaman, dan gangguan demi terwujudnya keamanan dan kesejahteraan seluruh aspek kehidupan bangsa. ${ }^{24}$

\footnotetext{
${ }^{24}$ Karmin, Surana, Konflik dan Solusi Laut Cina Selatan dan Dampaknya bagi Ketahanan Nasional, Majalah Tamnas Edisi 94
}

Berdasarkan pada UUD 1945, maka tugas dalam mempertahankan kedaulatan negara ini sangatlah penting. Akibat adanya kasus klaim atas wilayah Indonesia oleh Tiongkok, memberikan kita pelajaran penting betapa krusialnya wilayah perbatasan Indonesia. Sudah seyogyanya wilayah perbatasan menjadi perhatian khusus bagi Pemerintah Indonesia. Jangan sampai wilayahwilayah ini diklaim oleh negara tetangga terutama negara lain yang terletak ribuan mil dari Indonesia, karena kita tidak pernah memanfaatkan dan menggunakan wilayah tersebut sebagai penambah kesejahteraan rakyat atau bahkan untuk kepentingan nasional.

Disamping itu sangatlah penting konflik LTS untuk segera dapat terselesaikan dengan baik.Apabila tidak terselesaikan, disadari ataukah tidak bisa mengarah pada eskalasi konflik dengan Tiongkok, seperti halnya Vietnam dan Filipina yang sudah melibatkan penggunaan kekuatan militer meskipun dalam skala kecil.

\section{DAFTAR PUSTAKA}

Maksum, Ali, Regionalisme dan Kompleksitas Laut China Selatan, Jurnal Sosial Politik Universitas Muhammadiyah Yogyakarta, Volume 2 Nomor 2 (Januari-Juni 2017)

Kolonel Karmin Surana, SIP.,MAKonflik dan Solusi Laut Cina Selatan dan Dampaknya bagi Ketahanan Nasional, Majalah Tamnas Edisi 94-2012,

Tirtamulia, Tjondro, Zona-Zona Laut UNCLOS, Surabaya, Brilian Internasional, 2011

United Nation Convention of The Law Sea 1982

Undang-Undang Nomor 5 Tahun 1983 tentang Zona Ekonomi Ekslusif 


\section{Sichun Wu, Memahami Perspektif Tiongkok Dalam Upaya Penyelesaian Sengketa Laut Cina Selatan, Judul Buku (Solving Diputes for Regional Cooperation and Development in the South China Sea, A Chinese Perspective), Chandos Publishing, di terjemahkan oleh Peneliti Pusat Penelitian Politik, Lembaga IImu Pengetahuan Indonesia (25 Juni 2014)}

Kepentingan Politik China Dalam Konflik Region Sengketa Perebutan Territorial Kawasan Laut China Selatan, (https://www.academia.edu/93268 43/KEPENTINGAN POLITIK CHI NA DALAM KONFLIK REGION SENGKETA PEREBUTAN TERR ITORIAL KAWASAN LAUT CHIN A SELATAN) diakses pada $8 \mathrm{Mei}$ 2017

Ini Kronologi Penangkapan Kapal Ikan di Natuna Versi Koarmabar (http://nasional.kompas.com/read/2 016/06/21/12154071/ini.kronologi.p enangkapan.kapal.ikan.china.di.na tuna.versi.koarmabar) diakses pada 8 Mei 2017

Laut Tiongok Selatan (https://id.wikipedia.org/wiki/Laut T iongkok Selatan)

Apa Pengaruh Putusan Mahkamah Arbitrase Soal Laut Cina Selatan (www.bbc.com/indonesia/dunia/.../ 160711 dunia filipina cina mahk amah preview) diakses 29 April 2017Tjondro Titamulia, Zona-Zona Laut UNCLOS, Surabaya, Brilian Internasional, 2011 (hal 45-57)

Apa Pengaruh Putusan Mahkamah Arbitrase Soal Laut Cina Selatan (www.bbc.com/indonesia/dunia/.../ 160711 dunia filipina cina mahk amah preview) diakses 29 April 2017

Klaim Cina di Laut Cina Selatan 'tak punya landasan hukum (www.bbc.com/indonesia/dunia/20 16/07/160712_dunia_putusan_laut cinaselatan) diakses 9 Mei 2017

Menakar Efek Susulan Sengketa di Laut Cina Selatan (www.citizendaily.net) diakses pada 6 Mei 2017

U.S. Energy Information Administration (https://www.eia.gov/beta/international /regions-

topics.cfm?RegionTopiclD=SCS) diakses pada 29 April 2017 